\title{
Editorial sobre el trabajo: Inserción laboral del cirujano joven en la Ciudad de Buenos Aires. Necesidad de reestructuración del sistema de formación del cirujano general \\ Editorial on the article: Young surgeons entering the workforce in the City of Buenos Aires. Need for restructuring of the general surgery training system
}

Adelina Coturel*

En este número de la Revista Argentina de Cirugía, el Dr. Sarsur Fernández presenta el artículo "Inserción laboral del cirujano joven en la Ciudad de Buenos Aires. Necesidad de reestructuración del sistema de formación del cirujano general" ${ }^{1}$ donde se plantean dos problemas independientes pero estrechamente relacionados. A través de una encuesta, se intentó conocer si los egresados de los últimos años continuaban su ejercicio dentro de la Cirugía General o migraban a otras especialidades. Sobre la base de estos resultados proponen modificar el sistema de residencias para optimizar la asignación de recursos.

Actualmente, la Cirugía General se presenta como una especialidad en crisis, con una disminución en la cantidad de postulantes para formarse en ella, un aumento de la deserción durante la realización de la residencia y tasas importantes de burn out entre sus profesionales ${ }^{2}$. Esto se asocia a dos causas: la primera, que ocurre a nivel mundial, tiene que ver con el sistema formativo que impresiona ser obsoleto. La segunda, que ocurre al menos en la Argentina, está vinculada a las malas condiciones laborales del cirujano general.

Con respecto a la formación, el modelo de residencias médicas que utilizamos actualmente fue creado en el año 1899 por William Halsted en Estados Unidos, tomando la influencia del sistema de entrenamiento quirúrgico que había observado durante su paso por Europa. En la Argentina, este sistema se empezó a implementar en la década de 1950, cuando el Policlínico de Lanús (Htal. Gregorio Aráoz Alfaro) inició un programa de formación en cirugía. Luego, en 1957 se creó la primera residencia universitaria de Cirugía en el Hospital Durand ${ }^{3}$.

Pasaron más de 100 años y los avances en la tecnología y las telecomunicaciones han generado cambios profundos en la sociedad y en la práctica quirúrgica, que implicarían un cambio en la modalidad de enseñanza.
La generación que actualmente está en formación, los millenials, busca lograr un balance entre la vida profesional y laboral, por lo que es difícil que elija especialidades como la Cirugía General, que requiere largas horas en quirófano, gran demanda física, largos períodos de entrenamiento y una menor autonomía ${ }^{4}$. A su vez, la forma de aprender de esta generación es diferente de la forma en la que lo hicieron los que actualmente están encargados de la enseñanza y de la generación de los programas de Residencia ${ }^{5}$. Esta brecha produce un conflicto donde parece que los diferentes actores no logran entenderse.

Además, hay un aumento en la proporción de mujeres que eligen formarse como cirujanas, y este dato no es menor. Si bien no existe ninguna diferencia de género que impida que nosotras podamos realizar una cirugía de la misma o mejor manera que los hombres, el período formativo ocurre durante los años reproductivos de la mujer. Y todavía está "mal visto" que una residente quede embarazada, e incluso muchas fuimos discriminadas de algún cargo solo por la posibilidad de que en algún futuro tuviéramos hijos. Y esto no se limita al período formativo, ya que en una encuesta realizada a mujeres cirujanas, un $46 \%$ de las que no tenían hijos afirmaron que la maternidad no es compatible con su vida laboral, mientras que un $69 \%$ de las que ya tuvieron debieron cambiar su estilo de trabajo ${ }^{6}$.

Como si esto fuera poco, hay publicaciones que hablan de una falta de confianza para realizar procedimientos quirúrgicos entre los recién graduados de las residencias de Cirugía. Esto lo adjudican a la restricción del horario de las residencias, una disminución de la autonomía y un aumento en la complejidad de los casos. También podría deberse a factores sociales y políticos. Sin embargo, esto es algo discutido, ya que la mayoría de las encuestas son subjetivas y no se había estudiado el tema hasta el año 2003, por lo cual no hay datos de las generaciones anteriores ${ }^{7}$ 
Durante el año 2020 con la Comisión de Cirujanos Jóvenes de la Asociación Argentina de Cirugía comenzamos un Censo Nacional para identificar a los egresados de las residencias médicas de los últimos 5 años. Durante ese proceso, identificamos 178 instituciones que cuentan actualmente con programas activos de Cirugía General. Si bien hay sedes formadoras en 21 provincias, el $77 \%$ de ellas se concentra en la Provincia de Buenos Aires, Ciudad Autónoma de Buenos Aires, Córdoba y Santa Fe. Las plazas corresponden tanto a instituciones públicas (nacionales, provinciales y municipales), dependientes de Universidades, y privadas. Asimismo, entre estos hay centros de alta y de mediana complejidad.

El Ministerio de Salud de la Nación delega en la Asociación Argentina de Cirugía el proceso de acreditación de las residencias de Cirugía General. El objetivo de dicho proceso es asegurar la calidad de los programas que ya se encuentran en funcionamiento y promover la mejora de la formación en las residencias en Cirugía General a nivel nacional. Solo 44 (25\%) de las instituciones que identificamos con el censo tiene acreditación vigente a la fecha ${ }^{8}$, lo que implica que no conocemos el programa de formación con el que cuenta el $75 \%$ de las residencias del país y si este es acorde con las pautas generales propuestas por la Asociación.

Durante el censo, solicitamos a todas las instituciones que nos envíen la lista de residentes actuales y de egresados, y tuvimos una tasa de respuesta del 92\%. En el período comprendido entre los años 2015 y 2020 concluyeron la Residencia, por lo menos, 1611 personas, de las cuales 621 (39\%) son mujeres. Sabemos que otras especialidades quirúrgicas utilizan la residencia de Cirugía General como puente en su for- mación, por lo que en una segunda etapa del censo intentaremos responder cuántos de estos egresados permanecen ejerciendo dentro de la Cirugía General o sus ramas.

Para abordar la problemática de las condiciones laborales del cirujano general realizamos una encuesta a aquellos Miembros de la Asociación Argentina de Cirugía menores de 40 años. Obtuvimos 155 respuestas, con un promedio de edad de 35 años. El $72 \%$ de los encuestados fueron hombres. El 56\% había realizado el año de Jefatura de Residentes y un $77 \%$ se encontraba realizando, o ya había concluido, una subespecialidad. Entre las más elegidas figuraban Cirugía Coloproctológica, Hepato-bilio-pancreática, y Esofagogástrica. La mayoría de los cirujanos jóvenes que respondieron a la encuesta ejercían en la Ciudad Autónoma de Buenos Aires, la Provincia de Buenos Aires, o en ambas.

El 52\% de los encuestados trabajaba tanto en relación de dependencia como de forma autónoma, por prestación, lo que indicaría que tienen más de un trabajo. Además, el 53\% trabaja más de 60 horas semanales. El "poliempleo" y la excesiva carga horaria laboral actúan en detrimento de la formación continua de los cirujanos jóvenes y de su calidad de vida. Sumado a que el $84 \%$ considera que no está bien remunerado, la Cirugía General no parecería ser hoy en día una especialidad atractiva para elegir.

Podemos concluir que la problemática de nuestra especialidad es multifactorial y que hay que incluir a todos los actores para poder resolverla. Charles Darwin dijo: "No es la especie más fuerte la que sobrevive, ni la más inteligente, sino la que responde mejor al cambio" y este es el momento para la cirugía de cambiar.

—ENGLISH VERSION

In the article "Young surgeons entering the workforce in the City of Buenos Aires. Need for restructuring of the general surgery training system" ${ }^{11}$ published in this issue of Revista Argentina de Cirugia, Sarsur Fernandez et al. present two independent problems that are closely related. By means of a survey, the authors tried to find out whether the recent surgeon graduate trainees continued their practice in general surgery or moved to other specialties. Based on these results, they suggested modifying the residency system to optimize the allocation of resources.

Nowadays, general surgery is a specialty in crisis, with fewer applicants for training programs, greater number of dropouts during the residency program, and high burn-out rates among general surgeons ${ }^{2}$. This is associated with two factors: firstly, the training system appears to be obsolete worldwide, and secondly, the working conditions of general surgeons in our country are poor.

The medical residency model was created in the United States in 1899 by William Halsted, who was influenced by the training system in surgery he had observed during his stay in Europe. This model is still in use nowadays. In Argentina, the residency system started in the fifties with the implementation of a surgical training program at Policlínico de Lanús (Htal. 
Gregorio Araoz Alfaro). Then, in 1957 the first university surgery residency was created at Hospital Durand ${ }^{3}$.

Over 100 years have passed and the advances in technology and telecommunications have generated deep changes in society and surgical practice, which would result in changes in training models.

The generation that is currently in the process of training, the millennials, seek to achieve a balance between work and life, so it is difficult for them to choose specialties such as general surgery which requires long hours in the operating room, great physical demands, long training period and less autonomy ${ }^{4}$. In turn, the way this generation learns is different from the way those who are currently in charge of teaching and producing residency programs did $\mathrm{so}^{5}$. This gap generates a conflict where the different actors do not seem to understand each other.

In addition, the proportion of women who choose surgical training is increasing, and this is not a minor fact. While there are no sex differences that prevent women from performing surgery as good as or better than men, the training period occurs during a woman's reproductive years. A pregnant resident is still frowned upon, and many of us were even discriminated against from some position just because we might have children in the future. This is not limited to the training period; in a survey of female surgeons, $46 \%$ of those who did not have children stated that motherhood was not compatible with their working life, while $69 \%$ of those who already had children had to change their working style ${ }^{6}$. Some publications reported a lack of confidence to perform surgical procedures among graduating general surgery residents. This could be due to duty hour restrictions, decreased autonomy, greater operative complexity, and social and political factors. However, this is a matter of debate, since most surveys are subjective and the topic had not been explored until 2003 , so there are no data from previous generations ${ }^{7}$.

During 2020, the Committee of Young Surgeons of Asociación Argentina de Cirugía started a national census to identify general surgery residents who had graduated within the last 5 years. During that process, we identified 178 institutions with active general surgery programs. There are training centers in 21 provinces, and $77 \%$ of them correspond to the Province of Buenos Aires, the Autonomous City of Buenos Aires, Córdoba and Santa Fe. The positions are in public (national, provincial and municipal), university and private institutions corresponding to high and medium complexity centers.
The National Ministry of Health delegates the accreditation process of general surgery residencies to Asociación Argentina de Cirugía. The aim of this process is to ensure the quality of the programs already running and to promote improvement in general surgery residency programs at the national level. Only $44(25 \%)$ of the institutions identified in the census are currently accredited $^{8}$. This means that we ignore the training program of $75 \%$ of the residencies nationwide and if this program complies with the general guidelines proposed by the association.

During the census, we asked all the institutions to send us the list of current residents and graduate trainees and had a response rate of $92 \%$. Between 2015 and 2020 at least 1611 physicians completed the residency program; 621 (39\%) were women. We know that other surgical specialties use the general surgery residency as a bridge in their training; therefore, in a second stage of the census we tried to respond how many of these graduate trainees were still practicing general surgery or its branches.

We conducted a survey among members of Asociación Argentina de Cirugía < 40 years to tackle the problem of general surgeons' working conditions. We obtained 155 responses; mean age of survey respondents was 35 years and $72 \%$ were men. Fifty-six percent had been chief residents and $77 \%$ were either completing or had already finished a subspecialty. The most chosen subspecialties were colon and rectal surgery, hepato-pancreato-biliary surgery, and gastroesophageal surgery. Most of the young surgeons who responded the survey were practicing in the Autonomous City of Buenos Aires, the Province of Buenos Aires, or both.

Fifty-two percent of the respondents were both employees and self-employed, indicating that they had more than one job, and 53\% worked 60 hours per week or greater. Multiple job-holding and excessive workloads are detrimental to the continuing education of young surgeons and to their quality of life. In addition, as $84 \%$ of the respondents considered that they were not well paid, general surgery does not seem to be an attractive specialty to choose nowadays.

We can conclude that the problems of our specialty are related with multiple factors and that all the actors must be included to solve them. Charles Darwin said: "It is not the strongest of the species that survives, nor the most intelligent that survives. It is the one that is the most adaptable to change". This is the opportunity for surgery to change. 
Referencias bibliográficas / References

1. Sarsur Fernández HF, Buchanan LM, Cassani F, López MA, La Torre A. Inserción laboral del cirujano joven en la Ciudad de Buenos $\mathrm{Ai}$ res. Necesidad de reestructuración del sistema de formación del cirujano general. Rev Argent Cirug 2021;113(1):92-100

2. Landi $L$ y col. Conflictos del cirujano: ¿la vocación quirúrgica está en crisis? Rev Argent Cirug. 2020; 112(3):303-10.

3. Programa Docente de la Residencia de Cirugía General. Ministerio de Salud-Gobierno de la Ciudad de Buenos Aires. (2016). https:// www.buenosaires.gob.ar/sites/gcaba/files/programa_cirugiaweb-2016_0.pdf

4. Patti M, Kībbe M. Surgery 2019: an existencial crisis. Updates in Surgery.2019; 71:201-3.
5. Serafini V, Duhalde M, Ortíz E. Relato Oficial del $87^{\circ}$ Congreso Argentino de Cirugía 2016: Formación en cirugía abierta en la era videoscópica. Rev Argent Cirug. 2016; 108 (Suplemento 1):S63S202.

6. Cumpa López N, Gallino Fernández G. La mujer en cirugía: una exploración de las barreras en la carrera laboral. Rev Argent Cirug.2020; 112(1):30-42.

7. Elfenbein D. Have we created a crisis in confidence for general surgery residents? A systematic review and qualitative discourse analysis. JAMA Surg. 2016;151(12):1166-75.

8. Asociación Argentina de Cirugía-Residencias con acreditación vigente. http://aac.org.ar/cont_residencia_acred5.asp 